\title{
Literature Review on Methodological Aspects of Audit Independence \& Materiality Perspective
}

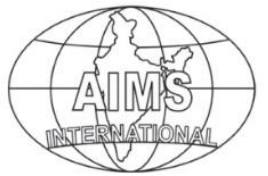

DOI: $10.26573 / 2021.15 .2 .1$

Volume 15, Number 2

May 2021, pp. 73-87

\author{
Athira A \\ Pankaj Kumar Baag \\ Indian Institute of Management \\ (athiraa12fpm@iimk.ac.in) \\ (baagpankaj@iimk.ac.in)
}

This paper focuses on the literature, contributes to the philosophy of audit materiality and auditor independence. The study covers a large period ranging from 1996 to 2019. Auditing provides an independent examination of the books and accounts. The concept of audit materiality and independence of the auditor plays a vital role in the process of expressing an opinion by the auditor. The level of materiality determines the reliability of the audit report and independence ensures the quality of the opinion. The major implications of the study indicate the importance of auditing standards and the improvement in the regulatory requirements.

Keywords: Audit Materiality, Auditor Independence, Literature Review

\section{Introduction}

Business can be defined as a collection of transactions (Jensen \& Meckling, 1976). The financial transactions should be recorded for future purposes in order to make sure the proper recording and analysis of the performance of an organization. Multiple stakeholders have different interest in an organization; hence the reporting requirement should be strong enough to satisfy the requirements of all the parties. Disclosure and reporting should be reliable to meet its main objectives. Auditing is one of the external aspects which is mandated by regulation all over the world. As per the Institute of Chartered Accountants of India Auditing is an independent examination of books and accounts (ICAI)".

Auditor independence ensures the integrity and objectivity of an audit function. Auditor's opinion should not be influenced by the direct or indirect behaviours or opinion of any interested parties such as managers, owners. Shareholders, debenture holders, customers, suppliers, etc. The concepts of auditing include various aspects such as materiality, audit plans, internal control, and audit opinion. Among these aspects, our paper concentrates on the audit materiality and various contributions of the literature to this area. Our paper reviews the literature contributions on this aspect, related theories and research methodologies used therein. This review covers literature contributions for a large period, ranging from 1996 to 2019.For the concept of independence, our paper review covers major contributions in the field for the last ten years. The major possible implications could be the standardisation of auditing standards and related rules and regulations. 


\section{Literature Review}

\section{Auditing Literature}

Audit literature is one of the richest contributed fields among accounting and auditing. The concentration of the literature shows a drastic shift from time to time. Till 2000's the area mostly concentrates on the fundamentals such as vouching, verification, internal control, audit materiality, auditor's independence, sources of audit evidence and audit risk. Our paper tries to explore the fundamental contributions in the field. After 2000's the literature shows some advanced shifts from these basic concepts, such as structure if internal control, related auditing standards, protection of auditor's independence, financial reporting standards, etc (Armitage, 2008). Audit independence and materiality are two important factors which decide the fair expression of view by the auditor on the financial statement.

The concept of materiality is related to misstatements, a misstatement or omission is considered to be material if the amount is individually or aggregately significant and which may affect the investment, financial, operational uses of the users of the financial statements (Baldacchino, Tabone, \& Demanuele, 2017). This concept had to use by the auditor both before and during the audit. During the planning, stage auditor ensures that she covers all the relevant transactions which are vulnerable to misstatements. This helps the auditor to form an opinion on the statement. However, the auditor has to make sure that the financial statement has been prepared in such a manner that is free from material misstatement and according to all reporting standards. Hence a big risk is associated with it, related to expressing an inappropriate opinion on a financial statement which is vulnerable in nature (Barndt, Fuller, \& Flynn, 2016).

Even though the concept of materiality looks easy by definition it involves difficulties in practical. The auditor has to use his discretion to decide the material area which affects the investors decisions (Vorhies, 2005). The auditor may decide the materiality of a transaction based on various features of the transaction such as the amount of transaction, parties involved in the transactions, the period of transactions, volume of transactions, etc. The determination of materiality is based on the auditor's professional judgment. Hence the auditor decides a materiality level based on the above-mentioned measures, and such limit can be called as performance materiality (Bell, Knechel, Payne, \& Willingham, 1998). Based on the materiality benchmark determined by the auditor, more than fifty percent of the income statement shows a profit which is less than the planned materiality level(Chen, Pany, \& Zhang, 2008).

\section{Qualitative Materiality}

The audit materiality is closely related to audit qualifications, as per the auditing standard the level of materiality constrained to the transactions which are having the minimum value of five percent of the sales of an organization. But the literature pointed out that the audit materiality concentrates on the qualitative aspects of a transaction than on a quantitative basis. Empirics prove that qualitative materiality gets more importance while taking audit adjustment decisions (T. B.-P. Ng \& Tan, 2007). According to (Corte, García, \& Laviada, 2010) the auditors express a qualified opinion on financial statements based the misstatements related to qualitative materiality as well, this conclusion is based on 473 samples first-hand data collected by the authors through interviews. Based on a large enough sample size the author 
generalizes the result to identical scenarios based on a positivistic method of accounting. The accounting and auditing profession face multiple issues and criticisms in recent periods.

\section{Order Effect on Materiality}

Information presentation order effects play a major role in deciding the audit materiality. Based on the qualitative information available to the auditor, she revises the thresh hold of materiality to ensure the quality of reporting which makes the misstatement qualitatively immaterial. The experience of an auditor in the field may decide her the inherent risk-taking capacity. The auditor's perception of materiality could be based on the order of information he receives. The cross-comparison of information flow helps the reviewer to overcome from the sequence response bias. Hence, she can mitigate it to an extent. The highly experienced auditor group shows greater order effect biases, (Brown, 2011).

\section{Audit Threshold}

The audit threshold determined by auditors may act as an important factor in reporting the misstatements, which decides the materiality of transactions to detect related errors and omissions. Debates over the misstatement's tolerance capacity of the auditing profession. The paper provides a model to decide the audit threshold of materially. The audit threshold can be considered as a trade of off audit materiality and misreporting. This provides a base for the regulators and the management to model a better auditing standard requirement. Hence the auditor decides upon the level of materiality based on the thresh hold she determines, taken into account various features of the transactions, her experience in the field, possible misstatements, vulnerabilities, and organizational setup.

\section{Audit Materiality as per Indian Context}

Auditing standard 320 deals with the materiality in planning and executing an audit. The Materiality can be considered as a qualitative as well as a qualitative concept. In Indian context the standards specify that an item is said to be quantitatively material if it's value in aggregate is greater than or equal to at least five percent of the aggregate sales level. But the standard is not limited to this boundary condition. It covers some qualitative aspects as well which is based on the professional judgment of the auditor.

Auditor considers the related audit risk to decide upon the materiality, frequency, value, type, and background, of transactions may be vulnerable to associated risk factors. Based on such factors the auditor may decide upon the nature of audits such as complete verification and vouching, surprise audit visits. The timing of the audit also is decided upon the relevance of the transactions and the maximum time the reviewer can devote to it by considering the time constraints. The materiality level decides for the whole financial statements, income statements, for particular accounts, or even a single party, particular account, classes of transactions.

Based on the associated audit risk, that is the ability of an auditor to handle the expression of an inappropriate opinion without affecting his credibility, acts as an important factor to decide materiality level. The revisions could take place for the existing nature, timing, and extent of the audit plan, when the audit progresses. The 
auditor used to document the plans and procedure, and the related revision to the plan. This standard is applicable to all companies in effect from $1^{\text {st }}$ April 2019.

\section{Role of the Audit Committee}

An audit committee is a group of directors that belongs to the board of directors, who act as an independent committee and oversight the preparation and presentation of the financial reporting. The audit committee performs a major role in deciding upon the materiality level. The external auditor has a significant dependence on the audit committee and the information supplied by them. Audit committee considered as an independent committee; hence the reliance of the auditor is justifiable (DeZoort, Hermanson, \& Houston, 2008). The committee act as an intermediary between the management of an organization and the auditors. It provides credible information to the auditor regarding the materiality of the transactions in the financial statements. Based on such information auditor plans the materiality map of an organization. The auditor uses positive theory while deciding upon the materiality, based on the available samples and further predictions the auditor arrives at an audit plan.

The empirical evidence provided by (DeZoort et al., 2008) concludes that the power of the audit committee has been increased after the introduction of the Sarbanes-Oxley Act. Hence the indirect interpretation could be that the audit committee has more influence on the reviewer of financial statements than earlier. Therefore, the auditors plan on materiality might be effect by audit committee opinion than before.

The public policy perspective says that the regulators are approaching the auditors and audit committees to discuss the materiality aspects and the audit adjustments proposed by the auditors but which are unaccommodated. The standard-setting board may consider the audit materiality aspects in a qualitative manner. It has empirically proved that the audit committee has been putting effort to improve the audit quality by setting a higher standard of materiality (DeZoort et al., 2008).

\section{Other Contributions}

The major contributions are highly diversified. Iyer \& Whitecotton, 2007 uses experimental case analysis method to study the importance of SAB 99 list. It states that several quantitatively immaterial factors become material in its qualitative terms and which is pure discretion of the auditor. The authors using the case study method of analysis, to study organizations and the management, to understand their view on the concept of qualitative materiality. Hence this helps the auditor to conceptualize on the managerial priority on materiality.

One of the experimental studies provides evidence regarding the propensity of an auditor to report the client's ability to report earnings over and above expected (T. B. $\mathrm{Ng}$, 2007). The organizations mainly use two types of earnings management mechanisms, that might be qualitative or purely quantitative. This experimental study proves that the auditor has a higher ability to detect and report quantitative misstatements in the client's financial statements while comparing to qualitative misstatements. Auditor has to put extra effort and professional judgment to detect the qualitative exaggerations in the earnings. The materiality is an important factor here. Availability of exact materiality guidance ensures the standard of audit materiality by the auditor. Hence this paper supports the requirement of well-established and structured standards of materiality. 
The audit materiality decisions taken by the reviewer under the pressure of the timeline is another area of study. The reviewer will be provided with very limited time to do the review. The audit could be an analysis of the yearly financial statements of an organization. Hence based on the rules and regulations of the countries the audit time deadline may vary from 3 months to six months after the completion of the financial year. Based on a design- methodology sample-based study, (Robertson, 2007) concludes that the audit quality reduces under the time pressure to complete an audit. The audit staff tries to avoid responsibility in such circumstances and which negatively affect the audit quality. The design study is based on a small sample consists of sixty-seven. Due to practical difficulties to conduct a real-time study the analysis of this study is based on the proxy samples. Instead of audit staff, they use the audit students as a proxy.

Materiality is an important concept in case of a continuous audit as well. The continuous audit could be internal or external audits. It is the review of the financial transactions of an organization on a recurrent basis during the financial year. This may be too long and interrupt the daily activities of an organization. More frequent and continuous audit motivates the study about materiality. (Vasarhelyi, 2007) studies the perception of the investors on materiality, and how the actual materiality the auditor plans for. The materiality estimates of the continuous audit might be different from statutory and one-time audit. This study investigates the basis to compute materiality in different circumstances. The perception of materiality could be different once the interim audit report is published by the company. Based on the measure of interim review report the investors make some ideas about the possible audit quality and ability of an auditor to measure the materiality of various items in the financial statements. Whereas (Shaub, 2005) explains the change in the meaning of materiality from time to time. Earlier materiality was a value-adding concept which focuses on the qualitative part of financial transactions. Recent scams pointed out that, for the new generation, auditor's the materiality is just a mathematical number which helps them to protect from other statutory obligations. The quantitative materiality limits the responsibility of the auditor to a certain amount of errors, omissions, and frauds. Hence petty expenses are prone to significant threat of misstatement because the auditor gives very less importance for such items. The auditing assurance standards on materiality institutionalize the concept, hence auditor tends to limit the truth-finding responsibility within the specified quantitative materiality. This provides a mechanized review report which any programmed computer system can generate.

From the beginning of time and crosswise over social and social settings, most frameworks of conviction - regardless of whether religious or mainstream - have credited knowledge to the individuals who consider reality to be what rises above the just material (Miller, 2005). However, as the investigations gathered here show, the insignificant isn't effectively isolated from the material. People are characterized, to an uncommon degree, by their demeanours of insignificant goals through material structures. The expositions in Materiality investigate changed signs of materiality from old occasions to the present. In evaluating the basic job of materiality in forming humankind, they signal the need to decanter the social inside social human sciences so as to account for the material.

Thinking about subjects as various as a religious philosophy, innovation, fund, and workmanship, the patrons - the majority of whom are anthropologists-look at the 
wide range of manners by which materiality has been comprehended and the outcomes of these distinctions. Their contextual investigations demonstrate that the most recent types of monetary exchanging instruments can be contrasted and the most established goals of old Egypt, that the guarantee of programming can be contrasted and a deep-rooted want for an unmediated relationship to heavenly nature.

In the case of concentrating on the religious philosophy of Islamic banking, Australian Aboriginal craftsmanship, subordinates exchanging Japan, or materials that react straightforwardly to their condition, each paper adds profundity and subtlety to the task that Materiality progresses: a significant affirmation and reconsidering of one of the essential properties of being human. Current year, as well as previous year misstatements, consider deciding upon the materiality level. The cumulative misstatement approach is one of the major methods of labeling materiality (Nelson, Smith, \& Palmrose, 2005).

Considering another scenario J. M. Horgan, 2003suggest a method to decide upon the optimum sample size to express an opinion by the auditor. This paper uses a series of simulation experiment to model the optimum sample size. So that it helps to minimize the error amount and maximizes the audit quality. Tuttle, Coller, \& Plumlee, 2002 studies about the impact of materiality on the market price of the stock, the study uses the experimental method, considering 12 independent auditors as a sample size. The findings show that the undisclosed material misstatement doesn't have any impact on the market price of the securities.

Similarly, Nelson et al., 2005 decisions provide experimental evidence regarding the use of cumulative misstatements as to the measure of materiality. The study considered various characteristics of misstatements, such as size, accuracy, documentation, profitability, asset size, etc. Under different contexts, the auditors insist the management disclose the materiality in a proper reporting manner, in order to mitigate the risk of expressing an inappropriate opinion.

Based on a small sample as evidence Hans, 2015 concludes that the high quality in the financial settings of the clients and the return on the asset may decrease the complexity of the client. Hence this reduces the information asymmetry, thereby the materiality would be more meaningful.

An auditor decides the aggregate materiality which is within the risk of financial statement errors. If the auditor is highly risk-taking, then the auditor may ready to accept the adjustments in the financial statement as the client required, whereas the auditor who set high standard of materiality level expresses a clean audit report after considering all audit adjustments, otherwise she will prefer audit report with certain degree of qualifications (David, Steven M. Glover, Jiambalvo, 2000). The audit adjustment may be considered the projected error and uncertainty with regard to the random samples of evidence that the auditor chosen.

In a recent study Ruhnke \& Schmidt, 2019 investigates the resolution of detected errors and its materiality. The paper suggests that the materiality standard should be based on the effect on income in the financial statements due to the adjustments made. It suggests the materiality level decision should be prior to the audit engagement. The total amount of detected adjustment is the deciding factor in this regard. Green\& Cheng, 2019 is an experimental study which does a materiality judgment for non-financial performance information in case of consolidated financial statements. The auditor should be able to identify the assurance resources which ensures the 
reliability of the financial statement. Hence the presence of a strategy map helps optimum allocation of such resources. Hence this paper contributes towards the standard settings towards materiality of non-financial factors.

The audit process requires an integrated holistic approach. The materiality of financial and non-financial factors is important in deciding the quality of auditor opinion. The concept of materiality should not always be an export decision, it could be a rationale decision as well. Such a holistic approach towards the materiality helps to bring multiple aspects of the possible misstatement. Canning, O'Dwyer, \& Georgakopoulos, 2019 suggests that the materiality standard could be more credible if it decides by the rationalist- no experts such as accountants and non-accountants. This idea helps to consider social cohesion as well. This paper contributes towards the audit of new area and how it extends to power the ocratization.

\section{Auditor Independence and Materiality}

Independence of an auditor is an important function of audit, which provides a dual advantage for the auditor, it helps to enhance the professional reputation to the auditor, and reliability to the opinion expressed by the auditor. Nasution \& Östermark, 2019 develops a model to determine awareness of the auditors to decide upon the professional reputation. This paper uses the questionnaire method to collect data, from practicing auditors to understand the validity and reliability of the new scale of independence proposed by the developer. The findings show that the unidimensional scaling of auditor independence and the concept of validity.

Audit materiality has direct relationship with the independence of the auditor. The decision of an auditor concerning materiality helps to decide upon the independence he possess over his profession. The very high materiality standards can be considered as the prerequisites for the independence of the auditor. The literature covers various aspects to explain both concepts. The major concepts are the audit fee and its impacts on independence, auditor rotation and tenure of the auditor, statutory requirements.

Real bookkeeping embarrassments in India, for example, Satyam PC administrations outrage have brought up an issue over examiner freedom. Indian controllers are on edge that the expanded residency of the evaluator in an association prompts an excessive amount of nature with the administration and other related gatherings, which may will in general bargain with the idea of examiner autonomy.

Audit quality is an important determinant of the quality of an opinion expressed by an auditor on a financial statement. The difficulty of measuring audit quality is the reason for the increasing importance of materiality and auditor independence. Since the auditor is an independent reviewer the possibility of measuring the quality will be lower. Audit quality portrays the ability of an auditor to detect the violations of generally accepted accounting principle (DeFond \& Zhang, 2014). Audit quality cannot be measured directly hence the literature use a large number of proxies to measure audit quality (Rajgopal, Srinivasan, Zheng, 2015).

The reviewers who finished their residency will not be reappointed in a similar organization as an evaluator for the following five years. The advocates of the idea of obligatory inspector pivot, contend that the confinement inferred on those evaluators who finished the residency determined by the demonstration help to guarantee the freedom of reviewers and in this way expanded review quality. Then again, the rivals of the required inspector revolution contend that the expanded review residency 
causes the evaluator to acquire learning about the customer association that prompts expanded review quality.

The auditor may engage the works other than audit, such as consultancy, legal and advisory services, company registration services, income tax filing services and goods and service tax return filing services, etc. If the auditor engages in any other services with the client other than auditing, then which may affect the dependence of the auditor. Auditor receives audit fee for audit services and non-audit fee for other services. Empirics proves that the audit quality decreases on an increase in the non-audit fee by the same auditor. In such circumstances, the auditor may collude with the management of the organization.

Reviewer autonomy alludes to the freedom of the inside inspector or of the outer evaluator from gatherings that may have a budgetary enthusiasm for the business being examined. Freedom requires uprightness and a targeted way to deal with the review procedure. The idea requires the examiner to do their work unreservedly and in a goal way.

Freedom of the inner examiner implies autonomy from gatherings whose interests may be hurt by the after effects of a review. Explicit inward administration issues are an insufficient hazard the executives, deficient inside controls, and poor administration. The Charter of Audit and the answering to an Audit Committee, for the most part, gives freedom from the executives, the code of morals of the organization (and of the Internal Audit calling) helps give direction on autonomy structure providers, customers, outsiders, and so forth.

The autonomy of the outer examiner implies freedom from gatherings that have an enthusiasm for the outcomes distributed in fiscal reports of an element. The help from and connection to the Audit Committee of the customer organization, the agreement and the legally binding reference to open bookkeeping guidelines/codes, for the most part, gives autonomy from the executives, the code of morals of the Public Accountant calling) helps give direction on freedom structure providers, customers, outsiders.

Certain independent audit committees may from by the organization to protect the independence of the auditor (Onulaka, Shubita, \& Combs, 2019). The audit committees ensure the independence of the reviewer. This paper uses a semi-structured interview in order to analyze the impact of non-audit fee on the audit quality and thereby the audit independence.

Literature mainly contributes to the theoretical framework of auditor's independence. Corporate governance mechanisms help to build a strong theoretical structure for auditor independence. Regulatory requirements regarding the audit maximum audit tenure, auditor rotation, non-audit fee are the other important deciding factors of the audit independence (Altmetric, 2010).

Professional ethics of the auditor is another deciding factor of the auditor independence (Mohamed \& Habib, 2013) The profession of a reviewer is expected to be maintain a high degree of professional ethics and integrity. The ethical standards are mentioned in the audit standards, rules and regulations. There is a causal relationship exists between professional ethics and audit quality. Literature deals with multiple models which optimizes the auditor independence. Lismawati, Abdul, \& Anis, 2018 gives the empirical evidence, through online and offline surveys, that the comforts of the auditor in the audit process work as a mediating factor of audit 
independence. Locus of control of the auditor is another factor helps to improve independence.

Auditor rotation in both partner and firm-level helps to maintain auditor independence. As per rules an auditor cannot hold his office more than a specified tenure, she has to be either removed or not to be reappointed as an auditor of the same organization. The spill over effect and audit specialization effects are the major two theories which are explaining the concept of audit rotation. The secularisation effect indicates that auditor independence increases with an increased tenure. Because the auditor will have more knowledge about the organization and its financial transactions. Hence, she can identify the possibility of misstatements in an easy way (Kamath, Huang, \& Moroney, 2018).

In a similar context Mitrendu, Roy, Sidhartha, 2007 studies about auditor independence and how it protects the interest of the benefiting parties. The accounting scandals and other frauds destroyed the integrity of the auditing field. This resulted in losing confidence in the audit reports. Hence the regulators have implemented various related rules to protect the interest of the stakeholders as a whole. The big four audit groups are one of the main attractions in audit independence. There is a preconceived notion that the big four auditors ensure more independence, on afraid of reputation loss and as a matter of integrity. Big four auditors are providing audit services to major public limited companies, and they have the responsibility to maintain the stability in the audit integrity. Empirics supports the increasing audit quality on the audit of big four auditors. Since they are following some basic standards for each audit they have conducted and the clear signing responsibility helps to ensure auditor independence. Hence, the literature supports high audit quality on big four audits (Mohamed \& Habib, 2013).

Considering a different scenario, Ali Naeem Jasim Al Ghani, 2018 reviews the effect of total quality management technique implemented in an organization on the auditor's independence. The high autonomy of an auditing profession helps to improve the quality of business processes. The complete autonomy to the auditor helps to review the financial aspects in an impartial manner. Hence the reporting of the scenario will be more accurate. That helps the organization to plan for a better-quality activity.

There is a criticism against the TQM-independence concept. The high autonomy of the reviewer may lead to management favouritism, collusion with management, misreporting, etc. Hence the study concludes that the auditor's independence contributes towards the total and high audit quality, but the favouritism should be controlled by auditor rotation. A major portion of literature covers the impact of the non-audit services on auditor's independence (Khasharmeh, 2018) (García, López-Gavira, \& Pérez-López, 2017). kang, 2019 pointed out an interesting result on this aspect. This paper is based on Korean samples. The non-audit fee pays by the audit client is based on their performance. A low-performance firm has an incentive to purchase such non- audit services at a higher rate. The high non-audit fee provides high-quality expert non audit services. Through such services the low-performance firms deliberately hide the possible misstatement that the auditor may find out. Hence the financial statement will be clean in prima facia. Hence the intention of the client to purchase the non-audit services at a higher rate should be considered in suspicion (Xingqiang Du, 2017). 
Literature extends to free food and amnesties as well. How will it affect auditor independence? In many organizations providing the food and accommodation amnesties to the auditor is part of organization culture. Hence in some other countries the basic amenities and travelling expenses are mandatory to provide. But the countries other than the countries with mandatory regulatory requirements may have an impact on auditor independence. The clients may try to create a bonding with the auditors by providing hospitality. Miheal, Elizabeth, 2017 studies the behavior of the auditor during economic depression. During the economic depression the degree of audit risk will be potentially high. Hence the auditor has to put more effort to find the misstatements in the financial statements. There could be extra fee concession requirement during this circumstance. The auditor might be reluctant to issue going concern opinion in audit report on a highly contingent situation exists. Theses external pressure weakens the auditor's independence. Hence the audit quality tends to decrease.

Considering a different aspect, Yu-Cheng Lin, Yu-Hsin Lu, Fang-Chi Lin, Yi-Chen $\mathrm{Lu}, 2003$ discusses the situation in which auditors' compromises with their independence. The auditor may compromise with his independence based on the type of client he deals with. If such client is important for him, then he will try to compromise with his independence through increased earnings management, even though such clients are suffering from a loss in their financial status. Therefore, the characteristics of the client and the risk acceptance capacity of the auditors are the main two factors which decide the independence of the reviewer. Ratnaningsih R.A. Putranto, 2013 studies the impact of corporate governance practices in the auditor's independence. This paper uses a cross-sectional survey to collect the required data for the analysis. The findings of the study prove that auditor independence has direct relationship with the intensity of the client relationship, other services provided by the auditor to the concerned firm, business relationship, and financial interest.

Christina Chiang, 2016 studies the link between the skepticism of a reviewer. The reviewer's independence is the main function of professional skepticism. An auditor should be more focused on his professional discretions, the degree of skepticism he possesses may say the dependency he has over his opinion. Hence the skepticism of an auditor helps to decide the degree of independence. The conscious and unconscious personal biases of an auditor may affect the skepticism. Framework and disclosure of the moral standards help the auditor to decide the behavioral standards. The auditor should be aware of the moral and ethical aspects of the decision he took. The auditor should be aware of the effect of such a decision on various stakeholders. The stakeholders could be anyone including the employees, customers, suppliers, investors or various interested parties. The auditor should be able to justify the decisions towards all the stakeholders of the statement.

Similarly, Allen Dalbie, 2005 examines the threat of independence and the further consequences if the auditor is not able to meet the basic requirement of independence. This study is based on the samples collected from the web-based sources of information. The samples categorize the reporting decision of the auditor into going concern and other than going concern. Certain auditors may have very high independence threat compared to other auditors. In such circumstances the reviewer may tend to express an unmodified opinion and used to do complete verification of the 
vouchers and ledger accounts. The effect of risk in the auditor's decision making may help to maintain the integrity of the auditor in his opinion.

\section{Conclusion}

Audit materiality is an important concept that decides the quality of the opinion expressed by the auditor. It can be defined as anything on which the auditor expresses his opinion, which may seriously affect the decisions of the users of the financial statements. The literature is considering the concept in with a high degree of prominence. The literature is using the positivistic method of research to understand the impact of professional judgment of the auditor on materiality. Materiality consists of qualitative as well as quantitative materiality. Quantitative materiality can be measured as in exact terms. But qualitative materiality is a matter of debate in literature. It is considering as a pure discretion of the reviewer who expresses his opinion on the financial statements.

Independence of an auditor is an important function of audit, which provides a dual advantage for the auditor, it helps to enhance the professional reputation to the auditor, and reliability to the opinion expressed by the auditor. Literature explores in this area of studies very widely. Literature mainly contributes to the theoretical framework of auditor's independence. Corporate governance mechanisms help to build a strong theoretical structure for auditor independence. Regulatory requirements regarding the audit maximum audit tenure, auditor rotation, non-audit fee are the other important deciding factors of the audit independence.

\section{References}

1. Ali Naeem Jasim Al Ghani. (n.d.). The impact of auditor independence on Total Quality Management-Google Search.

2. Allen Dalbie. (n.d.). Independence Threats, Litigation Risk, and the Auditor's Decision Process*_Blay_2005-Contemporary Accounting Research-Wiley Online Library. Retrieved September 15, 2019, from https://onlinelibrary.wiley.com/doi/abs/10.1506/5FQ9-ANEA-T8J0-U6GY

3. Altmetric, Listen, Research article, Enhancing auditors' independence in auditing enterprises in Vietnam, \& Le Doan Minh. (n.d.). Enhancing auditors' independence in auditing enterprises in Vietnam: Cogent Economics \& Finance: Vol 7, No 1. Retrieved September 15, 2019, from https://www.tandfonline.com/doi/full/10.1080/23322039.2019.1602240

4. Armitage, J. (2008). Changes in the importance of topics in auditing education: 2000-2005. Managerial Auditing Journal, 23(9), 935-959. https://doi.org/10.1108/02686900810908463.

5. Baldacchino, P. J., Tabone, N., \& Demanuele, R. (2017). Materiality disclosures in statutory auditing: A Maltese perspective. 42.

6. Barndt, R. J., Fuller, L. R., \& Flynn, K. E. (2016, September 6). Teaching Inherent Risk and Tolerable Misstatement in Auditing: A Modified Delphi Method as a Teaching Tool [Book-part]. https://doi.org/10.1108/S1085-462220160000019005 
7. Bell, T. B., Knechel, W. R., Payne, J. L., \& Willingham, J. J. (1998). An empirical investigation of the relationship between the computerization of accounting systems and the incidence and size of audit differences. Auditing, 17(1), 13.

8. Brown, C. A. (2011). Order Effects and the Audit Materiality Revision Choice. Journal of Applied Business Research (JABR), 25(1). https://doi.org/10.19030/jabr.v25i1.1046

9. Canning, M., O’Dwyer, B., \& Georgakopoulos, G. (2019). Processes of audit ability in sustainability assurance - the case of materiality construction. Accounting and Business Research, 49(1), 1-27. https://doi.org/10.1080/00014788.2018.1442208

10. Chen, H., Pany, K., \& Zhang, J. (2008). An analysis of the relationship between accounting restatements and quantitative benchmarks of audit planning materiality. Review of Accounting and Finance. https://doi.org/10.1108/14757700810898230

11. Christina Chiang. (n.d.). Conceptualising the linkage between professional scepticism and auditor independence | Request PDF. Retrieved September 15, 2019,

from https://www.researchgate.net/publication/301330213_Conceptualising_the_link age_between_professional_scepticism_and_auditor_independence

12. Corte, J. M. del, García, F. J. M., \& Laviada, A. F. (2010). Effective use of qualitative materiality factors: Evidence from Spain. Managerial Auditing Journal, 25(5), 458-483.

13. David, Steven M. Glover, Jiambalvo. (n.d.). Error Projection and Uncertainty in the Evaluation of Aggregate Error | AUDITING: A Journal of Practice \& Theory. Retrieved September 15, 2019, from https://aaapubs.org/doi/10.2308/aud.2000.19.1.79

14. DeFond, M., \& Zhang, J. (2014). A review of archival auditing research. Journal of Accounting and Economics, 58(2-3), 275-326. https://doi.org/10.1016/j.jacceco.2014.09.002

15. DeZoort, F. T., Hermanson, D. R., \& Houston, R. W. (2008). Audit Committee Member Support for Proposed Audit Adjustments: Pre-SOX versus Post-SOX Judgments. AUDITING: A Journal of Practice \& Theory, 27(1), 85-104. https://doi.org/10.2308/aud.2008.27.1.85

16. García, J. E. R., López-Gavira, R., \& Pérez-López, J. A. (2017). Servicios adicionales de auditoría. Independencia del auditor y permisividad de la legislación. Revista de ciencias sociales, 23(4), 9-22.

17. Green, W. J., \& Cheng, M. M. (2019). Materiality judgments in an integrated reporting setting: The effect of strategic relevance and strategy map. Accounting, Organizations and Society, 73, 1-14. https://doi.org/10.1016/j.aos.2018.07.001

18. Hans. (n.d.). Factors Affecting Auditors' Assessments of Planning Materiality | Request PDF. Retrieved September 15, 2019, from Research Gate website: https://www.researchgate.net/publication/247874206_Factors_Affecting_Audito rs'_Assessments_of_Planning_Materiality

19. Iyer, G., \& Whitecotton, S. (2007). Re-Defining "Materiality": An Exercise to Restore Ethical Financial Reporting. Advances in Accounting, 23, 49-83. https://doi.org/10.1016/S0882-6110(07) 23003-2 
20. Institute of chartered accountants of India Nature, Objective and Scope of Audit

21. J. M. Horgan. (n.d.). A list-sequential sampling scheme with applications in financial auditing. Retrieved September 15, 2019, from https://scite.ai/reports/a-list-sequential-sampling-scheme-with-jnmyJV

22. Jensen, M. C., \& Meckling, W. H. (1976). Theory of the firm: Managerial behavior, agency costs and ownership structure. Journal of Financial Economics, 3(4), 305-360. https://doi.org/10.1016/0304-405X(76)90026-X

23. Kamath, R., Huang, T.-C., \& Moroney, R. A. (2018). Auditor Rotation and Perceived Competence and Independence: The Effect of Fees and Industry Specialization. Journal of International Accounting Research, 17(3), 153-175. https://doi.org/10.2308/jiar-52227

24. Kang. (n.d.). Non-audit Services and Auditor Independence Depending on Client Performance-Kang - Australian Accounting Review-Wiley Online Library. Retrieved September 15, 2019, from https://onlinelibrary.wiley.com/doi/full/10.1111/auar.12243

25. Khasharmeh, H. (2018). Does the Provision of Non-Audit Services Affect Auditor Independence and Audit Quality? Evidence from Bahrain. Asian Academy of Management Journal of Accounting and Finance, 14(1), 25-55. https://doi.org/10.21315/aamjaf2018.14.1.2

26. Lismawati, Abdul, R., \& Anis, C. (2018). Optimizing of the Independence role on Performance Increase through the Comfortness of Auditors of Local Governments. E3S Web of Conferences, 73, 09015. https://doi.org/10.1051/e3sconf/20187309015

27. Miheal, Elizabeth. (n.d.). Client pressure and auditor independence: Evidence from the "Great Recession" of 2007-2009—Science Direct. Retrieved September 15, 2019, from https://www.sciencedirect.com/science/article/pii/S0278425417300455

28. Miller, D. (2005). Materiality (D. Miller, Ed.). Retrieved from http://www.dukeupress.edu/books.php3?isbn=978-0-8223-3530-6

29. Mitrendu, Roy, Sidhartha. (n.d.). Statutory Auditors' Independence in Protecting Stakeholders' Interest: An ... - Mitrendu Narayan Roy, Siddhartha Sankar Saha-Google Books," n.d. - Mittendorf, B. (2010). The role of audit thresholds in the misreporting of private information. Review of Accounting Studies, 15(2), 243-263. https://doi.org/10.1007/s11142-009-9088-5

30. Mohamed, D. M., \& Habib, M. H. (2013). Auditor independence, audit quality and the mandatory auditor rotation in Egypt. Education, Business and Society: Contemporary Middle Eastern Issues. https://doi.org/10.1108/EBS-07-2012-0035

31. Nasution, D., \& Östermark, R. (2019). The impact of auditors' awareness of the profession's reputation for independence on auditors' ethical judgement. Social Responsibility Journal. https://doi.org/10.1108/SRJ-05-2018-0117

32. Nelson, M. W., Smith, S. D., \& Palmrose, Z. (2005). The Effect of Quantitative Materiality Approach on Auditors' Adjustment Decisions. The Accounting Review, 80(3), 897-920. https://doi.org/10.2308/accr.2005.80.3.897

33. Ng, T. B. (2007). Auditors' Decisions on Audit Differences that Affect Significant Earnings Thresholds. AUDITING: A Journal of Practice \& Theory, 26(1), 71-89. https://doi.org/10.2308/aud.2007.26.1.71 
34. Ng, T. B.-P., \& Tan, H.-T. (2007). Effects of Qualitative Factor Salience, Expressed Client Concern, and Qualitative Materiality Thresholds on Auditors' Audit Adjustment Decisions (SSRN Scholarly Paper No. ID 980451). Retrieved from Social Science Research Network website: https://papers.ssrn.com/abstract=980451

35. Onulaka, P. N., Shubita, M. F., \& Combs, A. (2019). Non-audit fees and auditor independence: Nigerian evidence. Managerial Auditing Journal. https://doi.org/10.1108/MAJ-06-2017-1576

36. Rajgopal, Srinivasan, Zheng, S. R., Suraj Srinivasan, Xin Zheng. (2015). Measuring Audit Quality. pdf.

37. Ratnaningsih R.A. Putranto. (n.d.). Impact of auditor independence and good corporate governance companies on the quality audit (studies in public accountant firm in east Jakarta). Retrieved September 15, 2019, from https://www.researchgate.net/publication/322492027_Impact_of_auditor_indepe ndence_and_good_corporate_governance_companies_on_the_quality_audit_stu dies_in_public_accountant_firm_in_east_Jakarta

38. Robertson, J. C. (2007). Staff auditor reporting decisions under time deadline pressure. Managerial Auditing Journal.

https://doi.org/10.1108/02686900710741919

39. Ruhnke, K., \& Schmidt, M. (2019). The resolution of audit-detected misstatements. Journal of Applied Accounting Research, 20(1), 41-62. https://doi.org/10.1108/JAAR-08-2017-0079

40. Shaub, M. K. (2005). Materialism and materiality. International Journal of Accounting, Auditing and Performance Evaluation, 2(4), 347. https://doi.org/10.1504/IJAAPE.2005.009591

41. Tuttle, B., Coller, M., \& Plumlee, R. D. (2002). The Effect of Misstatements on Decisions of Financial Statement Users: An Experimental Investigation of Auditor Materiality Thresholds. AUDITING: A Journal of Practice \& Theory, 21(1), 11-27. https://doi.org/10.2308/aud.2002.21.1.11

42. Vasarhelyi, M. A. (n.d.). Chapter 12 Concepts in Continuous Assurance. 16

43. Vorhies, J. B. (2005). The New Importance of Materiality: CPAs Can Use This Familiar Concept to Identify Key Control Exceptions.

44. Xingqiang $\mathrm{Du}$. (n.d.). Hospitality and auditor independence: Do gifts blind the eyes?: China Journal of Accounting Studies: Vol 5, No 4. Retrieved September 15,2019 , from https://www.tandfonline.com/doi/abs/10.1080/21697213.2017.1423776

45. Yu-Cheng Lin, Yu-Hsin Lu, Fang-Chi Lin, Yi-Chen Lu. (n.d.). Net Losses and the Relationship between Auditor Independence and Client Importance: Evidence from a Cubist Regression-Tree Model | Journal of Emerging Technologies in Accounting. Retrieved September 15, 2019, from https://aaapubs.org/doi/abs/10.2308/jeta-51673 


\section{About Our Authors}

Athira A is PhD (FPM) student at Indian Institute of Management, Kozhikode, India in Finance, Accounting and Control area. Her research interest lies broadly in earnings management, auditing and taxation.

Pankaj Kumar Baag is an assistant professor at Indian Institute of Management, Kozhikode, India in Finance, Accounting and Control area. He has done FPM (PhD) from Indian Institute of Management, Calcutta. His research interest lies broadly in credit risk in banks, loan covenants, financial inclusion, corporate governance in banks and oil \& gas accounting. 